\section{Lembaran Sejarah}

\title{
The Dilemma of Knowledge Transfer in Early Independent Indonesia
}

\section{J. THOMAS LINDBLAD}

Leiden University

Email: thomaslindblad@hotmail.com

\begin{abstract}
This article addresses the dilemma of knowledge transfer at the time of decolonization and early independence in Indonesian history. There was an urgently felt need to replace Dutch knowledge as far as possible with knowledge held by Indonesians or imported from foreign countries other than the Netherlands. Concurrently, from the time of Indonesia's independence there was also a necessity to retain or gain access to practical knowledge required for economic development The article argues that this dilemma was resolved by a mix of policies geared towards different levels of sophistication of the knowledge involved. The article contains a brief theoretical treatment of this dilemma, followed by a global overview of policies implemented. A separate case study on the key banking sector serves to demonstrate the possibilities and constraints in effectuating a transfer of knowledge soon after independence.
\end{abstract}

\begin{abstract}
Abstrak
Artikel ini membahas dilema transfer pengetahuan pada periode dekolonisasi dan awal kemerdekaan Indonesia. Terdapat kebutuhan yang terasa untuk menggantikan sebanyak mungkin pengetahuan Belanda dengan pengetahuan dari orang Indonesia atau pengetahuan yang diimpor dari negara-negara lain selain Belanda. Pada saat bersamaan, semenjak kemerdekaan Indonesia ada pula kebutuhan untuk mempertahankan atau mendapatkan pengetahuan praktis yang dibutuhkan untuk pembangunan ekonomi. Artikel ini berargumen bahwa dilema ini diselesaikan lewat beragam kebijakan yang berbeda pada tiap ragam tingkat pengetahuan yang berbeda. Artikel ini berisi diskusi teoretis singkat mengenai dilema tersebut dan dilanjutkan dengan gambaran umum akan kebijakan-kebijakan yang diambil. Sebuah studi kasus pada sektor perbankan digunakan untuk menunjukkan kemungkinan dan keterbatasan yang dihadapi dalam mewujudkan transfer pengetahuan setelah kemerdekaan.
\end{abstract}

Keywords: banking; decolonization; knowledge transfer; nationalization

Kata Kunci: dekolonisasi; nasionalisasi; perbankan; transfer pengetahuan 


\section{Introduction}

In the charming movie 'Habibie \& Ainun 3' we see tangible evidence of extant Dutch expertise in newly independent Indonesia. It is 1955, Ainun is a first-year student at the Faculty of Medicine of the Universitas Indonesia in Jakarta. The Dutch professor enters the classroom and addresses the students in Dutch, assuming they will all understand since they are all graduates from high schools where the medium of instruction was Dutch. This indeed applied to the Dago Christian High School at Bandung that was attended by Ainun and Rudy Habibie. Three years later, in 1958, all Dutch professors were expelled from Indonesia in the wake of takeovers of Dutch-owned private enterprises all over Indonesia. Ainun's fiancé Achmad, a student of law and, incidentally, the son of one of the Indonesian medical professors, comments: 'It is unwise to get rid of available knowledge before you have built up your own knowledge.' A fellow student sees it differently: 'We have been instilled with Dutch thinking for three and a half centuries; it's time to get input from other countries.'

These statements illustrate the essential dilemma of a transfer of knowledge at the time of decolonization and early independence. A newly sovereign nation wishes to liberate itself from knowledge associated with the colonial past. Knowledge is here understood as the reservoir of accumulated information, understanding and skills available in the nation. It is useful to make a distinction between knowledge in a general sense and knowhow or practical knowledge needed for performing specific tasks. This article argues that the issue of a post-colonial transfer of knowledge needs to be addressed by differentiating between types of knowledge by levels of sophistication. Not all knowledge is easily replaced, some knowhow will have to be retained for a smooth operation of economy and society. In policymaking this may result in a variety of simultaneous approaches across a spectrum extending from enforced rapid change to gradual accommodation.

The article contains three sections. The first one is a brief theoretical discussion on the differentiation between types of knowledge based on levels of sophistication. This is followed by a global overview of policies and actions in this vein during the early independence period in Indonesia. The third section presents a case study on commercial banking, a key branch of the financial services sector using highly specialized knowhow. The conclusion sums up the links between the theoretical concepts and the historical evidence.

\section{Differentiation by level of sophistication}

Hasri Ainun spent another six years of medical study in Jakarta, whereas

1) The movie 'Habibie \& Ainun 3' was directed by Hanung Bramantyo and released in December 2019. Only three months before, on 11 September 2019, Indonesia's third president B.J. Habibie had passed away at the age of 83 years. The movie forms the sequel to 'Habibie \& Ainun' (2012) and 'Rudy Habibie' (2016). 
Bacharuddin Jusuf Habibie graduated in 1960 as an aeronautical engineer at the Rhine-Westphalian Technological University in Aachen in Germany, from there continuing to his doctorate, which he obtained in 1965. Their joint experience brings out the obvious point that a substantial investment in time and energy is required to obtain proficiency in a field applying advanced technology. Moving beyond the perspective of two talented individuals, we may infer that the transfer of knowledge in newly independent Indonesia was conditioned, amongst others, by the level of sophistication of the knowledge in question.

Independence, not only politically but also in terms of knowledge, was even more pressing since access to advanced technology was virtually monopolized by Dutch firms and Dutch residents remaining in Indonesia after the transfer of sovereignty. But knowledge comes at different levels of abstraction or sophistication. The challenge of knowledge transfer could only be taken up by applying a variety of approaches; there was no one size fits all approach. Types of knowledge are classified below in ascending order of sophistication.

The most readily accessible knowhow was not monopolized by the colonial elite. Examples from the economy include operational experience accumulated by senior Indonesian personnel in charge of productive resources in Dutch-owned firms. Evidence from the Indonesian Revolution testifies to Indonesian employees keeping Dutch firms running in Republican territory, albeit at less than full capacity. A case in point is the Dutch-owned cement factory at Padang in West Sumatra prior to the Dutch military reconquest of the region (Lindblad, 2009: 180). In the commercial sector we encounter the establishment and rapid expansion of indigenous Indonesia trading firms during the Japanese occupation and afterwards. Names of family businesses such as Dasaad, Pardede and Bakrie immediately come to mind (Post, 1997: 93-94). For this type of knowledge, it was essentially a matter of investing in general education to enhance the potential for knowledge transfers to the Indonesian population at large in the future.

A second category refers to knowhow at a medium level of sophistication, in particular supervision and management in private production. These were professional tasks performed by those with considerable experience or some degree of formal training. The main impediment here was the legacy of the education system under Dutch colonial rule. The strict segregation by ethnic origin, as laid down in the Government Statutes (Regeeringsreglement) of 1854 , translated as a sharply divided hierarchy in the educational system. Proficiency in Dutch was a prerequisite for access to higher education. As a result, Indonesia was bequeathed with a very tiny intellectual indigenous elite. On top of it, the privileged few of indigenous origin who pursued higher education in Dutch had a professed preference for working in civil 
service rather than in private business (Booth, 1998: 270-272). Possibilities for indigenous Indonesians to be promoted to higher positions were constrained by both a reluctance on the part of the Dutch or other foreign owners and the acute shortage of qualified personnel. An effective transfer of this type of knowledge required an investment in formal training in the immediate or short term. For a full utilization of the new nation's capabilities, it was also imperative to gain full control over the nation's productive resources.

A third and final category refers to knowhow at an advanced level of sophistication, that is knowledge that could only be acquired by extensive formal training underpinned by a considerable investment of capital. Examples include the medical sciences, aviation, commercial banking, and engineering in oil refining; this list is not exhaustive. Here we find the highest degree of monopolization by the colonial elite. A transfer of such knowledge presupposed a long-run commitment, investment and, not least important, patience.

Admittedly, this is a crude typology much in need of further elaboration. Still, it seems possible to link it with the range of policies for knowledge transfer that were implemented in Indonesia during the 1950s.

\section{Steps in the right direction}

There was an early awareness among the Republican leadership that something needed to be done about the nation's access to knowledge and intellectual resources. Not coincidentally, the negotiators for the Republic at the Round Table Conference in The Hague in late 1949 insisted upon an obligation by Dutch business firms to cooperate in promoting Indonesian staff in supervisory and management functions. This commitment was a foremost Indonesian precondition for continued operations by Dutch private enterprises in Indonesia following the transfer of sovereignty. Regrettably, however, no deadlines or targets were specified except for an envisioned general outcome in which a majority of supervisory positions were fulfilled by Indonesians (Lindblad, 2008: 149-150). By imposing a similar obligation on non-Dutch foreign business as well, the Indonesian government in 1950 made it clear that indonesianisasi (Indonesianization) was not just a matter of decolonization but also a way to generally enhance control over the nation's productive resources by its own people (Donnithorne, 1954: 27). Promotion of Indonesian supervisors and managers in private business formed a concerted effort at a transfer of knowledge at a medium level of sophistication.

The transfer of sovereignty on 27 December 1949 implied the replacement of Dutch civil servants by Indonesians. The commensurate transfer of knowledge was effectuated through recruitment of senior Indonesian civil servants from the tiny elite of Indonesians who had pursued 
Dutch education, including those who had studied at universities in the Netherlands, notably Leiden University. These Indonesians were often placed above their former Dutch superiors. The number of Dutchmen in the Indonesian civil service declined gradually during the 1950s. This illustrates a rather pragmatic approach of retaining access for a while to knowhow that could not immediately be replaced.

An early measure after the transfer of sovereignty was the discouragement of the use of Dutch as a language of instruction in education. This policy was applied from 1950 onwards in primary schools and from 1951 in secondary schools. It tore down the walls of segregation between the different types of primary schools and served to increase the number of students eligible for secondary education. It constituted a massive investment in general education geared towards expanding readily available knowledge at the moderate level of sophistication. Results were impressive, at any rate in quantitative terms. School enrolment in Indonesia is reported to have risen from 4 per cent in the late 1930s to 10 per cent in 1960 (Booth, 2010: 71).

The outcome in qualitative terms, however, was ambiguous. In response to the disappearance of Dutch as a language of instruction, private foundations began sponsoring Dutch-language schools throughout Indonesia. Nearly 100 of them were said to have been established by the late 1950s (Groeneboer, 1998: 291). The effect was paradoxical. Graduates from public schools were less qualified than before when applying for higher positions in Dutch-owned businesses, whereas graduates from private schools still enjoyed their language advantage.

University education was from 1952, at least formally, subject to eliminating the use of Dutch. But the teaching staff was largely Dutch-trained and the students came from schools where Dutch had been the language of instruction. The universities opted to keep Dutch lecturers for as long as possible but asked them to teach in English. Dutch professors set the tone at for instance, the new Faculty of Economics at Universitas Indonesia in Jakarta, which had been set up by the influential young economist Sumitro Djojohadikusumo, who himself had obtained his doctorate at the Erasmus University of Rotterdam (then Economische Hogeschool) (Weber \& Schulte Nordholt, 2010: 48-49). With considerable foresight, Sumitro as Dean of the Faculty already in 1957 began replacing Dutch economists with Americans. The policy pursued in tertiary education formed yet another example of a pragmatic approach necessitated by the high level of sophistication of the knowledge involved.

It goes without saying that the Indonesian government attached a high priority to gaining control over public transport, in particular aviation and inter-island shipping. In March 1950, the Indonesian national carrier Garuda was founded as a joint venture with KLM. At that time, there 
were scarcely any Indonesian pilots to be found. The Dutch partner KLM offered training programmes for Indonesian staff who would replace Dutch employees in the future. The joint venture came to an end in 1954 when the Indonesian government purchased the shares held by KLM, but the training programmes continued (Abriyanto, 1995). This was yet another example of pragmatism by gradually scheduling the transfer of knowhow at the high level of sophistication.

The situation was different in inter-island shipping since knowhow was more readily available, and its level of sophistication was lower. There were, after all, a lot of experienced sea captains available in the archipelago. A similar arrangement, as in the case of Garuda, would have been feasible in the form of a joint venture between the Indonesian state and the Dutch shipping company KPM (Koninklijke Paketvaart Maatschappij) that still largely controlled inter-island shipping. But KPM refused to cooperate and in 1952 the Indonesian government responded by setting up PELNI (Pelajaran Nasional Indonesia, Indonesian National Shipping) as a national rival (á Campo, 1998). The failure to find a solution meant a continuing Dutch shipping hegemony in Indonesian waters up to 1958.

In the meantime, the indonesianisasi of the personnel in Dutch-owned firms continued in compliance with the 'gentlemen's agreement' reached at the Round Table Conference. Progress varied a great deal dependent on the type of industry. Many firms in the commercial agriculture and trading sectors experienced little change before 1958, whereas some firms did witness some achievements in the right direction. In some instances, positions open to non-Dutch staff were filled by Indonesians of Chinese descent, whereas the intention of the Indonesian delegates at the Round Table Conference had been to promote indigenous Indonesians. By and large, progress made was considered too slow by both the Indonesian authorities and the trade unions but too fast by the Dutch owners (Lindblad, 2008: 166-171).

The final step in indonesianisasi was the takeover of Dutch firms in a chain of events from December 1957 (Sutter, 1959: 2). The takeovers were done by local trade unions but were soon endorsed by the Indonesian government and subsequently placed under military supervision. Only after a year, in December 1958, was legislation for formal nationalization promulgated, and it was effectuated in early or mid-1959. This completely changed the situation for a transfer of knowledge in Indonesia.

There was now an acute need for a speedy transfer of knowledge in large parts of the Indonesian economy. Dutch managers and administrators departed and were promptly replaced by senior indigenous Indonesian staff members, sometimes by military personnel, sometimes by Indonesians of Chinese descent with management experience in trading. Crash courses in management were set up in Jakarta and Bogor. In September 1958, an 
embryonic business school opened its doors in Jakarta. The catch-up in knowledge transfer was accelerated, sometimes hastily since it was driven by sheer necessity to keep the businesses running (Lindblad, 2008: 186-191). The year 1958 saw a most extraordinary situation in the Indonesian economy that regrettably has not yet been systematically researched. The Dutch companies were still the legal property of their Dutch owners and remained so up to early or mid-1959, but most Dutch managers had left. In legal terms, it was a situation in which the Indonesians were running somebody else's business.

There were notable exemptions made during the process of taking over Dutch enterprises in the late 1950s. The reason was sometimes the firm's legal status being a joint venture with non-Dutch foreign owners; this was the case with Royal Dutch Shell and Unilever. On occasions, the exemption was also due to particular bottlenecks in the transfer of knowledge following immediate appropriation. This brings us to our case study concerning commercial banking.

\section{Bankers' quest for continuity}

The commercial banking sector was of vital importance to the Indonesian economy because it facilitated international financial transactions. It used highly specialized knowhow that was indispensable and in short supply. During the colonial period, commercial banking had been strictly segregated along ethnic lines with access to specialized knowhow being restricted to the Dutch professional staff of four leading Dutch-owned banks: NHM (Nederlandsche Handel-Maatschappij, Netherlands Trading Association), NIHB (Nederlandsch-Indische Handels Bank, Netherlands Indies Trading Bank), NIEB (Nederlandsch-Indische Escompto Bank), and De Javasche Bank (the Java Bank, which also functioned as the colony's central bank). These four, complemented by a few smaller Dutch banks such as the Koloniale Bank, competed with international banks doing business in Asia, notably HSBC (Hongkong-Shanghai Banking Corporation), OCBC (Overseas Chinese Banking Cooperation), the Bank of China and a couple of Japanese belonging to the conglomerates Mitsui and Mitsubishi.

In 1940, combined equity of leading Dutch and other foreign banks amounted to nearly 800 million guilders. ${ }^{2}$ It can be reasonably assumed that investment and credit within the colonial Indonesian economy were by and large handled by the leading Dutch banks, whereas the other foreign banks primarily maintained local branch offices for foreign exchange purposes. ${ }^{3}$ The largest domestic bank at the time of independence was part of the Oei Tiong

2) Data on the equity of individual private enterprises in colonial Indonesia may be found in the statistical data base at the website colonialbusinessindonesia.nl.

3) Ample evidence of lending practices and priorities is available in the archive of De Javasche Bank at Bank Indonesia in Jakarta. 
Ham Concern in Semarang, citing equity at only four million guilders, a far cry from the leading Dutch-owned banks.

From the transfer of sovereignty onwards, international banking in Indonesia was regulated in detail by the authorities. The number of foreign banks permitted to handle transactions with foreign countries was limited to four, including three major Dutch banks: NHM, Nationale Handelsbank (formerly NIHB) and Escompto Bank (formerly NIEM). The other four were HSBC, OCBC, Chartered Bank and the Bank of China. According to one estimate, 75 per cent of the combined equity of these seven banks was in Dutch hands (Lindblad, 2008: 86-87).

The main bottleneck in the indonesianisasi of international banking operations after 1950 was the acute shortage of banking knowhow among Indonesians, especially indigenous Indonesians. This had already been acknowledged before the transfer of sovereignty. In November 1949, a group of leading Indonesian economists, who were in the Netherlands to attend the Round Table Conference, held discussions with Dutch bankers about setting up training facilities for Indonesians. The delegation included Vice President Hatta, Djuanda as well as Margono and his son Sumitro Djojohadikusumo. Their efforts however, were in vain (Lindblad, 2008: 63).

The issue of which knowledge to retain and which to replace came to a head with the choice of the young nation's central bank. During the Indonesian Revolution, when the archipelago was effectively split into two countries, each had had a central bank of its own. The traditional role of the Java Bank remained intact in Dutch-controlled areas, whereas the Republic established BNI (Bank Negara Indonesia,Indonesian State Bank) to serve as its central bank. At the transfer of sovereignty, the Indonesian government thus had a choice of two banks, both with experience from functioning as a central bank. The Republican government, represented by Hatta and Armed Forces Chief of Staff T.B. Simatupang, opted for the Java Bank arguing that this institution possessed the necessary knowhow, which the BNI did yet have. Sumitro Djojohadikusumo voiced a dissenting opinion suggesting that this was like choosing the KNIL (Koninklijk Nederlandsch-Indisch Leger, Royal Netherlands Indies Army) rather than TNI (Tentara Nasional Indonesia, Indonesian Armed Forces) to protect the nation (Thee, 2003: 58-59). As a result, central banking in early independent Indonesia remained a Dutch prerogative.

The pace of change was slow at the Java Bank. All senior directors were Dutchmen, the cashiers were all Chinese, whilst indigenous Indonesians performed supporting and administrative tasks. In 1951 the Indonesian government acquired all shares in the Java Bank and in 1953 the bank's name was changed to Bank Indonesia (Lindblad, 2005: 19-23). The President of the bank from 1951 was Syafruddin Prawiranegara, who had studied law at 
Leiden University. He continued to conduct board meetings in Dutch, presiding over a board consisting entirely of Dutch bank directors. He was a man with pragmatic views who remained at his post until 1958 when he took issue with Sukarno on the takeover of Dutch enterprises (Thee, 2003: 81).

In the meantime, initiatives were taken to develop knowhow among Indonesian bank employees. The authorities urged the Dutch banks to contribute to indonesianisasi by not replacing staff who were being repatriated to the Netherlands with Dutchmen but with Indonesians. But progress was slow in the opinion of the government. At the NHM, seventy-seven new staff members were recruited during the years 1951-1954, of which only fourteen were Indonesians. All local branches in the archipelago were headed by a Dutchman. Out of the fifteen new staff in 1956, only two were Indonesians. On the eve of the takeover of Dutch firms in December 1957, just one in seven of the management staff was not Dutch at the NHM (de Graaf, 2012: 376). The situation was no better in the other Dutch-owned banks. In 1954 the Handelsbank promoted twenty Indonesian employees to higher staff positions but only after considerable pressure from the government (Korthals Altes, 2004: 414-415).

Dissatisfied with the willingness of Dutch banks to disseminate knowhow to Indonesian staff, the government took its own measures in close cooperation with leading domestic banks such as Bank Indonesia, BNI and BIN (Bank Industri Negara, the State Industry Bank). A separate foundation, Yayasan Pendidikan Kader Bank (Bank Cadre Education Foundation), was set up to facilitate training of Indonesians in banking. By 1957, almost 340 bank employees had reportedly completed their courses (Lindblad, 2008: 87). Acquisition of specialized knowledge required for commercial banking was sped up in preparation for abandoning the pragmatic approach of relying on Dutch knowhow.

The massive takeover of Dutch businesses and departure of thousands of Dutchmen in late 1957 and early 1958 were viewed with alarm by the Dutch bankers. With an eye to the high level of sophistication in required knowhow, the Dutch banks expected to be exempted from appropriation, at any rate for the time being. As it turned out, this did not eventuate. By January 1958, the credit transactions of Dutch banks were put under direct military supervision. In April 1958, the supervision of Dutch banks was transferred to a newly created government institution, Badan Pengawas Bank-Bank Pusat (Central Bank Oversight Board). The Handelsbank lost its right to conduct foreign exchange operations in November 1958 and in January 1959 the Escompto Bank was nationalized and liquidated with immediate effect; it then became BDN (Bank Dagang Negara, Ştate Trading Bank). The Handelsbank followed suit in November 1959 and became the state-owned BUNEG (Bank Umum Negara, State Public Bank), which later become Bank Bumi Daya (Korthals Altes, 2004: 427-431). 
But the NHM was still operating unchanged from its palatial head office at Kota in Jakarta. The situation only underwent radical change in 1960, although the estates managed by NHM had been placed under Indonesian supervision one year earlier. In June 1960, NHM lost its right to engage in foreign exchange transaction and in November all branch offices were put under direct Indonesian supervision. Formal nationalization followed on 5 December 1960, retrospectively from December 1957. All facilities were transferred to the newly founded BKTN (Bank Koperasi, Tani dan Nelayan, Farmers and Fishers Cooperative Bank) and eventually, in 1965, incorporated into BNI with one unit later becoming Bank Exim (Export-Import Bank) (de Graaf, 2012: 374-378).

The NHM escaped nationalization a little longer than the other Dutch banks, which can be explained in one of two ways. One explanation stresses the cooperative attitude of the NHM directors towards the Indonesian government (Korthals Altes, 2004: 397). The alternative explanation points to the great economic importance of the knowhow available at NHM (de Graaf, 2012: 379). I am inclined to give more weight to the latter argument. The transfer of knowhow of such a high level of sophistication necessitated a pragmatic approach that was applied in consecutive stages. At first with the designation of the new nation's central bank, then subsequently with retained operations and limited indonesianisasi in Dutch banks throughout almost the entire decade of the 1950s, finally with the delayed takeover and nationalization of this foremost Dutch bank in Indonesia.

\section{Conclusion}

Economic decolonization was at its height during the early independence period in Indonesia and it was linked to an intellectual decolonization, a transfer of knowledge associated with Dutch colonial rule to Indonesian knowledge. This article emphasizes the essential dilemma of a knowledge transfer under the circumstances of newly acquired independence. There was a political urgency to reduce dependence on knowledge held or even monopolized by Dutch firms and Dutchmen remaining in Indonesia after the transfer of sovereignty. At the same time, there was an equally urgent need to retain access to such knowledge for purposes of national economic development. A range of diverse policies was applied to resolve this dilemma from the transfer of sovereignty to the final takeover of Dutch-held resources and the departure of Dutch residents.

The main argument here is that the different policies were geared to the level of sophistication of the knowledge to be transferred. For clarity of argument, a typology of knowledge has been created based on three categories in ascending order of sophistication. For the category of readily available knowledge, the key priority was to invest in general education to enhance 
future possibilities of knowledge transfer. For the category of knowledge at a medium level of sophistication, the main device was a trajectory of indonesianisasi resulting in a successive replacement of Dutch (or other foreign) supervisors and managers in private business by Indonesian nationals. For the category of highly sophisticated knowledge, including advanced technology, the most pragmatic approach was chosen as illustrated by delayed transfers of knowhow in university teaching, aviation, and commercial banking.

In any event, actual transfers of knowledge did not follow the pattern suggested by such an abstract construction. Admittedly, much progress was made in general education, at least in a quantitative sense. Yet, knowledge transfer by way of indonesianisasi proceeded far less smoothly and it became increasingly apparent that full control over economic resources was required too. The pragmatic approach in selected areas worked in the short run but was eventually incompatible with a situation in which Dutch economic resources were nationalized.

Returning for a moment to the movie 'Habibie \& Ainun 3', we may affirm that Ainun's onetime fiancé Achmad was probably a sensible young man, but he did not correctly read the signs of his times.

\section{Bibliography}

Abriyanto, M. Garuda Indonesia: Pengisi kemerdekaan bangsa. Jakarta: Garuda Indonesia, 1995.

Booth, Anne. The Indonesian Economy in the Nineteenth and Twentieth Centuries: A History of Missed Opportunities. London: Macmillan, 1998.

Booth, Anne. 'Government and Welfare in the New Republic: Indonesia in the 1950s', Itinerario. International Journal on the History of European Expansion and Global Interaction, Vol. 34 (1), 2010, pp. 57-76.

Campo, J.N.F.M. á. 'Business not as Usual: Dutch Shipping in Independent Indonesia', International Journal of Maritime History, Vol. 10 (2), 1998, pp. 1-39.

Donnithorne, Audrey. 'Western Enterprise in Indonesia Today', Pacific Affairs, Vol. 27, pp. 27-40.

Graaf, Ton de. Voor Handel en Maatschappij: Geschiedenis van de Nederlandsche HandelMaatschappij 18241964. PhD dissertation, University of Utrecht, 2012.

Groeneboer, Kees. The Dutch Language in Colonial Indonesia, 1600-1950: A History of Language. Amsterdam: Amsterdam University Press, 1998.

Korthals Altes, W.L. Tussen cultures en kredieten: Een institutionele geschiedenis van de Nederlandsch-Indische Handelsbank en Nationale Handelsbank, 1863-1964. Amsterdam: NIBESVV, 2004.

Lindblad, J. Thomas. 'From Java Bank to Bank Indonesia: A Case Study of indonesianisasi in Practice', Lembaran Sejarah, Vol. 8 (2), 2005, pp. 15-32.

Lindblad, J. Thomas. Bridges to New Business: The Economic Decolonization of Indonesia. Leiden: KITLV Press, 2008.

Lindblad, J. Thomas. 'The Economic Decolonization of Sumatra', New Zealand Journal of Asian Studies, Vol. 11 (10), 2009, pp. 178-188.

Post, Peter. 'The Formation of the Pribumi Business Elite in Indonesia, 1930s-1940s', 
in: Peter Post \& Ellen Touwen-Bouwsma (eds), Japan, Indonesia and the War. Leiden: KITLV Press, 1997, pp. 87-110.

Sutter, John O. Indonesianisasi: A Historical Survey of the Role of Politics in the Institutions of a Changing Economy from the Second World War to the Eve of the General Election, 1940-1955. PhD thesis, Cornell University, Ithaca, NY, 1959.

Thee Kian Wie (ed.). Recollections: The Indonesian Economy, 1950s-1990s. Singapore: Institute of Southeast Asian Studies, 2003.

Weber, Andrew \& Henk Schulte Nordholt. 'Interview with Thee Kian Wie', in: J. Thomas Lindblad \& Bambang Purwanto (eds), Merajut sejarah ekonomi Indonesia: Essays in honour of Thee Kian Wie, 75 years birthday. Yogyakarta: Ombak, 2010, pp. 41-88. 